\title{
ANTI-INFLAMMATORY EFFECTS OF PROPOXAZEPAM ON DIFFERENT MODELS OF INFLAMMATION
}

\author{
*N.Ya. Golovenko, T.A. Kabanova, S.A. Andronati, \\ O.I. Halimova, V.B. Larionov, A.S. Reder \\ A.V. BOGATSKY PHYSICO-CHEMICAL INSTITUTE OF THE NATIONAL ACADEMY OF SCIENCES \\ OF UKRAINE, ODESA, UKRAINE
}

\begin{abstract}
Background. Propoxazepam, 7-bromo-5-(2-chlorophenyl)-3-propoxy-1H-benzo[e][1,4]diazepin-2(3H)-one, is a promising analgesic and anticonvulsant and is on preclinical trial.

Objective. The aim of the research was to study the anti-inflammatory and analgesic action of Propoxazepam.

Methods. The anti-inflammatory action was evaluated by carrageenan induced rat paw edema, formalininduced paw licking response in mice and bradykinin-induced pain response in rat models.

Results. It was established for the first time that the administration of Propoxazepam caused a significant anti-inflammatory activity when tested in different in vivo chemical experimental models of induced inflammation, i.e. carrageenan-, bradykinin- and formalin-induced inflammation tests.

Conclusions. Propoxazepam significantly reduced acute and sub-acute inflammation and proved its efficacy and similar to anti-inflammatory action.
\end{abstract}

KEY WORDS: propoxazepam; diclofenac sodium; anti-inflammatory effect; carrageenan; formalin.

\section{Introduction}

Benzodiazepines are a large and still expanding group of synthetic heterocyclic derivatives. The wide spectrum of the pharmacological effects exhibited by these compounds makes them one of the most versatile class of drugs used in psychopharmacology. Classical 1.4-benzodiazepine (BDZ) drugs have sedative, anxiolytic and anticonvulsant properties, enhancing the gamma - aminobutyric acid (GABA)-ergic neurotransmission through binding to the specific BDZ recognition sites, within GABAA receptor-ion channel complex, and allosterically modulate its activity [1]. Almost since their introduction, there has been interest to the therapeutic use of the benzodiazepines for management of pain. As regarding many other drugs, initially developed and studied for indications other than pain, conclusive data regarding the analgesic activity of BDZ is lacking. A relevant aspect of neuroplastic changes in inflammatory and neuropathic conditions is reduction in inhibitory glycinergic and GABAergic control of dorsal horn neurons: a reduction in the GABAA-mediated endogenous

*Corresponding Author: Nikolay Ya. Golovenko, A.V. Bogatsky Physico-Chemical Institute of the National Academy of Sciences of Ukraine, Lyustdorfskaya road, 86, Odesa, 65080, Ukraine.

E-mail:n.golovenko@gmail.com inhibitory control within the central nervous system leads to exaggerated pain and hyperalgesia [2]. Potentiation of GABAA receptormediated synaptic inhibition by benzodiazepines reverses pathologically increased pain sensitivity in animal studies. Though BDZ and barbiturates have discriminating effects on pain, their pharmacological actions on the CNS are mediated through the GABA induced chloride currents [3]. In contrast to phenobarbitone, diazepam has also been reported to have anti-inflammatory action [4] and antipyretic action $[5,6]$.

A number of 3-substituted 1.4-benzodiazepines have been synthesized at the PhysicoChemical Institute of the National Academy of Sciences of Ukraine and their structure - activity relationships, have been studied as well. Their pharmacological effect was unusual, because unlike most classical BDS, in the models of nociceptive and neuropathic pain these substances showed significant analgesic activity [7]. One of them, Propoxazepam, 7-bromo-5(2-chlorophenyl)-3-propoxy-1H-benzo[e][1,4] diazepin-2(3H)-one, is a promising drug and is on preclinical trials [8]. Like gabapentin and pregabalin, which are well-known drugs used in general medical practice for treatment of neuropathic pain [9], Propoxazepam also has 
an anticonvulsant effect $[10,11]$, which explains the analgesic component of the pharmacological spectrum.

An inflammatory response and development of pain are interdependent processes. The uncontrolled inflammatory reaction triggers the process of chronic pain generation, which is associated with the phenomena of central sensitization and neuroplasticity. It becomes obvious that the main direction of complex analgesic therapy should be the targeted use of pharmacological agents possessing antiinflammatory potential [4-6].

It has been established that acute diazepam (a BDZ derivative drug) treatment suppresses cell proliferation in rat thymus, decreases interleukin release from mouse macrophages [12] and decreases macrophage and neutrophil activities [13], most probably by affecting the peripheral-type benzodiazepine receptor (PBR) present in these immune/inflammatory cells. High doses of diazepam (10.0-20.0 mg/kg) have proved to reduce the volume of acute inflammatory paw edema in rats as a response to carrageenan administration [14]. This effect was associated with an action of diazepam on the PBR present in the adrenal and/or immune/ inflammatory cells [15].

Therefore, the objective of the study was to investigate the possible anti-inflammatory effects of the innovative derivative of BDZ Propoxazepam on acute and chronic inflammatory responses in the rats exploring the possible underlying mechanisms involved in these anti-inflammatory effects.

\section{Methods}

\section{Animals and Injection Procedures}

Male Wistar rats (180-210 g in weight) and white mice (20-24 g in weight), took from Institute of Pharmacology and Toxicology of the NAMS of Ukraine, kept at the local animal facility, were used. The animals were exposed to a 12-hour light-dark cycle and were provided with food and water ad libitum. All experiments were conducted during the light part of the day (9.00-14.00). The experiments were carried out according to the recommendations of the Committee for Research and Ethical Issues of the IASP (1983) and were approved by the local ethical committee for animal research. All manipulations were performed to minimize animal suffering and to reduce the number of animals used.

The test compound was suspended in Tween 80 (1\%) emulsion, and the control animals received corresponding amount of vehicle (1\% Tween 80$)$.

\section{Drugs and Chemicals}

Propoxazepam was synthesized according to the method described in [16]. The structure of the substance was determined and approved by a complex of physicochemical methods (IR and mass spectroscopy, as well as X-ray diffraction analysis) [17]. Chemical purity was confirmed by elemental analysis (99\%). Sodium carrageenan and bradykinin were obtained from Sigma Chemical Co., USA. Diclofenac sodium salt (Merck). Various other chemicals and reagents were of analytical grade and got from local firms.

The doses of Propoxazepam for experiments on animals were chosen according to previous bioscreening and pharmacodynamic data, where the analgesic properties of Propoxazepam were estimated. For rat tests the mean effective dose $\left(E D_{50}\right)$ in the tail flick test was $1.83 \mathrm{mg} / \mathrm{kg}$, so in this species of animals for paw edema tests the doses were raised in 1.6 (for $3 \mathrm{mg} / \mathrm{kg}$ ) and 5 times (for $10 \mathrm{mg} / \mathrm{kg}$ ) in order to achieve expected $82 \%(1 \sigma)$ and $95 \%(2 \sigma)$ effect. Mice doses were derived according to allometric relations with regard to species and body weight coefficients.

\section{Carrageenan-Induced Rat Paw Edema}

Three groups of eight rats each were administered with the vehicle (Tween 80 (1\%) emulsion, p.o.), the test compound (3 or $10 \mathrm{mg} / \mathrm{kg}$, p.o.), and diclofenac sodium (10 mg/kg, p.o.). One hour following the treatment with various agents, edema was induced by a subplantar injection of $0.1 \mathrm{~mL}$ of $1 \%$ of freshly prepared suspension of carrageenan into the right hind paw of each animal. The volume of the injected paws was estimated at 0; 2 and $4 \mathrm{~h}$ following carrageenan injection utilizing a plethysmometer (Plethismometer, Ugo Basil, Italy). The edema development was determined by the increase in paw volume. The increase in percentage inhibition was calculated utilizing the following equations:

Percentage inhibition $=\left(\Delta \mathrm{V}_{\mathrm{K}}-\Delta \mathrm{V}_{\mathrm{A}} / \Delta \mathrm{V}_{\mathrm{K}}\right) \cdot 100 \%$,

Where: $\Delta \mathrm{V}_{\mathrm{K}}$ - mean paw size in the control group.

$\Delta \mathrm{V}_{\mathrm{A}}$ - mean paw size in the treated group. Mice

Formalin-Induced Paw Licking Response in

Mice were divided into four groups $(n=6)$. Test drugs Propoxazepam (0.01, 0.1 and $3.0 \mathrm{mg} / \mathrm{kg}$ p.o.), diclofenac sodium (10 mg/kg p.o.) and control vehicle (1\% Tween 80, p.o.) were administered $1 \mathrm{~h}$ before formalin injection into the 
animals in the first set (early phase) and $40 \mathrm{~min}$ before formalin injection into the animals in the second set (late phase), respectively. Mice were subcutaneously injected with $20 \mu$ of formalin ( $1 \%$ in normal saline) into the right dorsal hind paw. The amount of time that the animal spent licking the injected paw was measured during the first 5 min (Phase 1, corresponding to the direct chemical stimulation of nociceptors) and 20-25 min after formalin injection (Phase 2, inflammatory).

\section{Bradykinin-Induced pain response in rat}

The possible contribution of bradykinin receptors in the antinociceptive effect of propoxazepam was evaluated by using the method described by Chau et al [18]. Bradykinin (0.01\% solution) was injected to the subplantar area of rat right hind paw $0.1 \mathrm{ml} /$ animal. Propoxazepam $(1.83 \mathrm{mg} / \mathrm{kg})$ was administered 2 hours prior to bradykinin injection. The degree of hyperalgesia was determined using a dolorimeter (Dolorimeter Baseline, USA) by determination of the threshold of pain sensitivity (TPS) - the minimum pressure on the lower surface of the rat's foot $\left(\mathrm{g} / \mathrm{mm}^{2}\right)$, which caused pain in the animal (vocalization and/or withdrawal of the foot). Each animal was given 5 attempts; the threshold value was taken with such a pressure force, which caused a positive response in at least one attempt. The TPS was compared on intact and damaged limbs on the $14^{\text {th }}$ day after tying (pathology without treatment), as well as on the injured limb in 2 hours (peak of action) after the drugs administration.

\section{Data Analysis}

Data are expressed as a mean and standard error mean (SEM) and a Student's t-test was used to compare the data of the control and standard groups. Probabilities ( $p$ ) of $<0.05$ were considered statistically significant. Statistical analysis was performed using the standard statistical package of MS Excel.

\section{Results \\ Effects of Propoxazepam on Acute Inflam-} mation

A single sub-plantar injection of carrageenan induced an increase in the paw thickness within 24 hours. The rat group pretreated with Propoxazepam had a significantly reduced $(p<0.05)$ increase in the paw thickness in 2 hours with $36.7 \%,(3.0 \mathrm{mg} / \mathrm{kg})$ and $47.0 \%(10 \mathrm{mg} / \mathrm{kg})$ reduction of the paw edema and in 4 hours $25.0 \%(3.0 \mathrm{mg} / \mathrm{kg})$ and $26.7 \%(10 \mathrm{mg} / \mathrm{kg})$. While rats of the group pretreated with diclofenac sodium showed $47.0 \%$ and $26.7 \%(p<0.0001)$ reduction of the paw edema, respectively (Table 1).

Effect of Propoxazepam on FormalinInduced Inflammation

As shown in Figure 1, the i.p. treatment with Propoxazepam at the doses of $0.01,0.10$ and $3.0 \mathrm{mg} / \mathrm{kg}$ significantly inhibited the licking time in of both neurogenic (0-5 $\mathrm{min})$, by $91.9 \%$ $(p<0.001), 76.0 \%(p<0.001)$, and $15.0 \%$, and inflammatory $(15-30 \mathrm{~min})$, by $98.4 \%(p<0.001)$, $54.0 \%(p<0.001)$, and $32.1 \%(p<0.01)$, phases of formalin-induced paw-licking test compare to the control group. Diclofenac sodium $(10,0 \mathrm{mg} / \mathrm{kg}$, i.p.) significantly inhibited both phases of the test by $51.0 \%$ and $53.6 \%(p<0.001)$, respectively.

Propoxazepam Antinociceptive Action on the Bradykinin-Induced Hyperalgesia

Bradykinin injection to the rats induced statistically significant TPS decrease by $71.7 \%$ (Fig. 2). Under these conditions Propoxazepam induced prominent antibradykinin effect, since on the background of its administration bradykinin induced TPS decrease was threefold less that of in the control group $(23.8 \%$ and $71.7 \%$ respectively).

\section{Discussion}

The study proves the anti-inflammatory and analgesic effect of Propoxazepam on different models of inflammation. The carrageenaninduced rat paw edema model is widely used to investigate mechanisms of inflammatory processes and to screen potential anti-inflammatory agents. This model has been extensively studied in the assessment of anti-inflammatory action of steroidal and non-steroidal drugs involving several chemical mediators such as histamine, serotonin, bradykinin and prostaglandins. The edema and inflammation induced by carrageenan is established to be mediated by histamine and $5-\mathrm{HT}$ during the first hour, after which increased vascular permeability is maintained by the release of kinins up to 2.30 hours and from 2.30 to 6 hours, the mediators are found to be the prostaglandins, the release of which is closely associated with migration of leucocytes into the inflamed site [19,20].

In carrageenan-induced paw edema test, the highest inhibitory activity was exhibited at the dose of $10 \mathrm{mg} / \mathrm{kg}$ compared to the other dose. This simply depicts that the higher the dose, the more the inhibition of the edema. Hence, an inhibitory activity of Propoxazepam is dose-dependent (Table 1).

The results of the study have revealed that Propoxazepam as well as diazepam has a sig- 


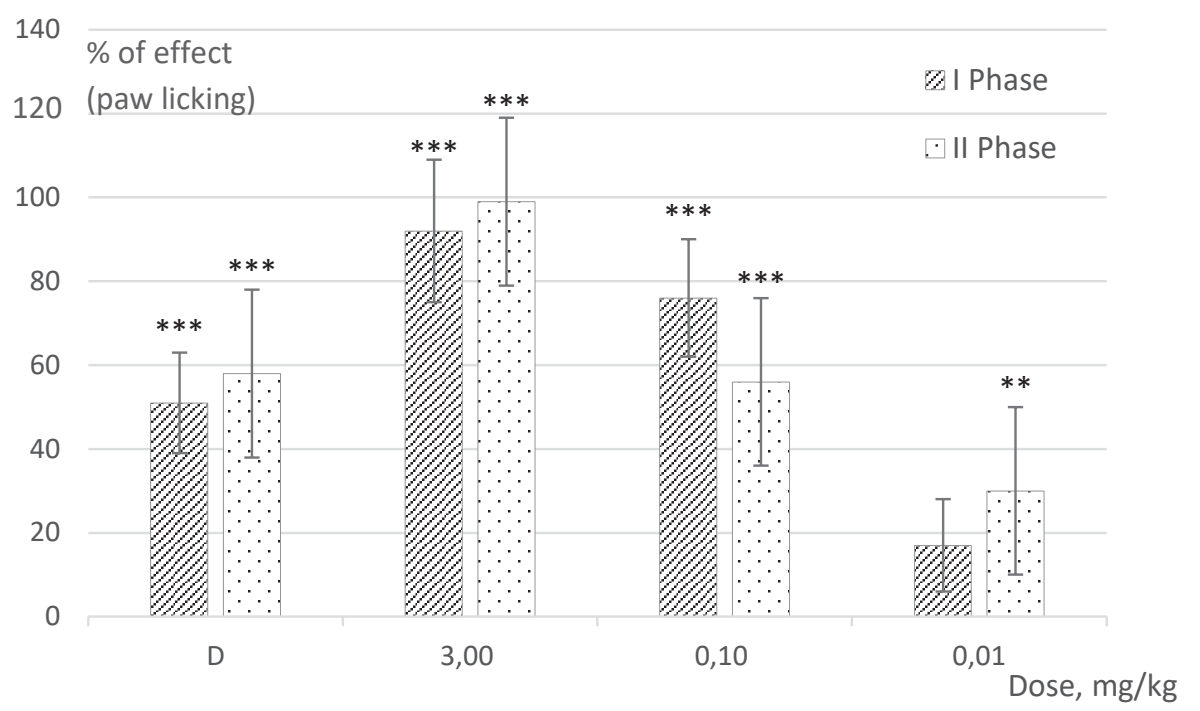

Figure 1. Effect of Propoxazepam and Diclofenac Sodium on the paw licking induced by a formalin injection in mice. Results are presented as mean \pm SEM $(n=6)$.

$* *-p<0.01, * * *-p<0.001$, compared to the control.

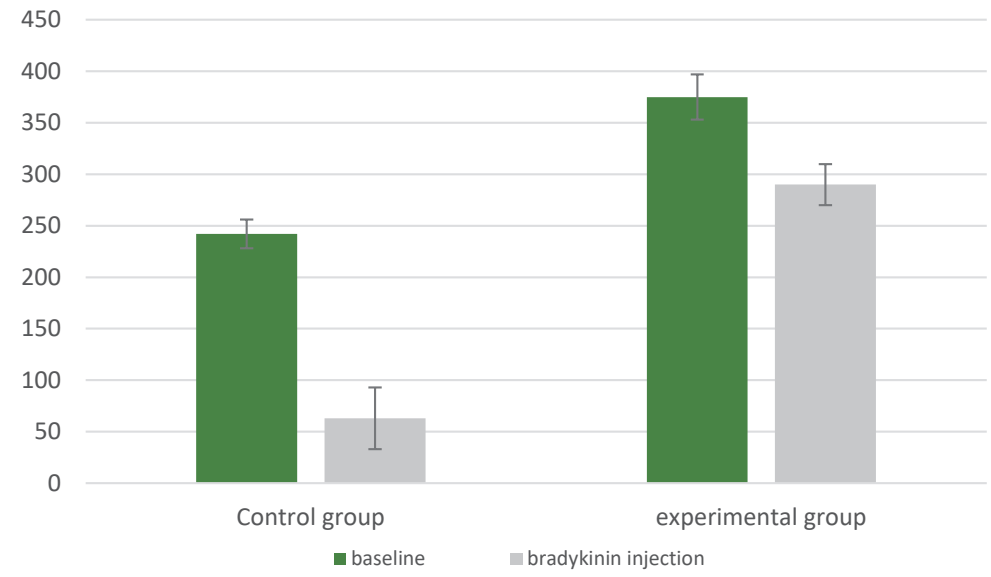

Figure 2. Effect of propoxazepam ( $2 \mathrm{mg} / \mathrm{kg}$ p.o.) on bradykinin-induced hyperalgesia in rats. Pressure induced hind paw withdrawal were evaluated before (baseline), and in 1 min after intraplantar bradykinin $(0.01 \%)$ administration. Two hours before examination the control group received vehicle, and the experimental group received propoxazepam.

Data are presented as a mean \pm SEM, $n=7$. * $-p<0.05$ versus baseline, ${ }^{*}-p<0.05$ versus vehicle.

nificant anti-inflammatory effect on the different experimental models of inflammation either acute or chronic. In the acute inflammatory study, diazepam caused significant reduction of carrageenan-induced paw edema and serum $\mathrm{NO}_{x}$ levels in rats. While in the chronic inflammatory study, diazepam led to significant reduction of the paw thickness, significant reduction in the serum C-reactive protein, significant increase in serum albumin and significant increase in the serum corticosterone level $[21,22]$. Similar pharmacological actions have been reported for chlordiazepoxide while, alprazolam is reported to be devoid of

Table 1. Change in paw size by carrageenan-induced paw edema in albino rats treated with increased doses of Propoxazepam

\begin{tabular}{|l|c|c|c|}
\hline \multicolumn{1}{|c|}{ Treatment } & $\begin{array}{c}\text { Dose, } \\
\mathrm{mg} / \mathrm{kg}\end{array}$ & $\begin{array}{c}\text { Percentage inhibition (\%) } \\
\text { after } 2 \text { hours }\end{array}$ & $\begin{array}{c}\text { Percentage inhibition (\%) } \\
\text { after 4 hours }\end{array}$ \\
\hline Propoxazepam & 3.0 & $36.7 \pm 4.1 * \star$ & $25.00 \pm 2.7 *$ \\
& 10.0 & $47.0 \pm 4.1 * \star \star$ & $26.70 \pm 5.4 *$ \\
\hline Diclofenac Sodium & 10.0 & $43.0 \pm 7.0 * \star \star$ & $57.10 \pm 8.3 * \star *$ \\
\hline
\end{tabular}

Notes. Values are expressed as Mean \pm SEM of eight rats, * $-p<0.05, * *-p<0.001, * * *-p<0.0001$ (Student's t-test). 
analgesic activity [23]. These reports clearly indicate that various benzodiazepines differ individually in their pharmacological profiles despite of the common chemical structure. Furthermore, the results of chronic inflammatory study showed that diazepam significantly increased serum albumin level and significantly decreased serum C-reactive protein, which is an acute phase protein commonly used to assess the disease activity in inflammatory rheumatic diseases, and this effect of diazepam could be explained by the fact that it can suppress secretion of pro-inflammatory cytokines from mouse macrophages such as TNF-a, IL-1, and IL-6, which is the main stimulator of acute phase protein synthesis in acute and chronic inflammation [24]. Structurally Propoxazepam is closer to diazepam and chlordiazepoxide, therefore their mechanisms of action coincide.

The formalin-induced licking response is used as a model for evaluation of new analgesic. This definitely proves whether the licking is genuinely due to formalin injected into the paw, because at times the animals lick the forepaw under normal physiological conditions. However, formalin test is sensitive to non-steroidal anti-inflammatory drugs and other mild analgesics. The test possesses two distinct phases, possibly reflecting different stages of pain. The early phase reflects a direct effect of formalin on nociceptors (non-inflammatory pain), whereas the late phase reflects inflammatory pain [25]. Moreover, formalin-induced nociception is also associated with direct action on a member of Transient Receptor Potential family (TRP) of cation channels denoted as TRPA1 receptor located in C fibers [26]. The results of the study show that the i.p. administration of Propoxazepam significantly and dose-dependently attenuates the nociceptive response in both neurogenic and inflammatory phases of the formalin-induced paw-licking test in mice at the level reference drug diclofenac sodium. The effect of diazepam is very similar to the effect of Propoxazepam in formalin-induced licking model [27]. The effect of diazepam is confined to increase the pain scores during the periods in 10, 15, and 20 min after formalin.

One of the cardinal features of inflammatory states is that normally innocuous stimuli produces pain [28]. Bradykinin, one of the peptide kinins, is an important inflammatory mediator. The main function of bradykinin is to increase the sensation of pain. A secondary function of bradykinin is to promote the production of histamine that is of increasing blood flow into the involved area by dilation of arteries and increased capillary vessel permeability [29].

Bradykinin diversely influences on the pathophysiological processes accompanying pain and inflammation. Its biological action is mediated by two established G-protein coupled receptors named B1 and B2. The bradykinin B2 receptor is constitutively expressed in most cell types and evokes acute pain responses following tissue injury, whereas the bradykinin B1 receptor is induced during inflammatory insults or painful stimuli [30].

The attained results show that Propoxazepam in this experiment reduces hyperalgesia on the in the model of bradykinininduced edema. An additional argument for possible interaction of Propoxazepam with bradykinin receptors is the study [31] of compound influence on the maximal normalized speed of bradykinin-induced contraction of the rat stomach smooth muscles in the presence of gadolinium ions and verapamil. For Propoxazepam the statistically significant changes of the before-mentioned indicator have been shown as it is able to additionally inhibit the bradykinin-induced contraction in the presence of $\mathrm{Gd}^{3+}$ and verapamil by $19.3 \%$ and $32.0 \%$ respectively, and demonstrates the effects similar to those of des-Arg9-bradykinin-acetate (B2-bradykinin receptors concurrent antagonist) that proves either interaction with receptor or influence on signal transduction pathways.

Additionally, the mechanisms and antinociceptive effects of propoxazepam were studied on animal models of acute and chronic pain $[7,8]$. The effects of Propoxazepam on pain responses were examined using tail-flick test (TFT) in rats, streptozotocin-induced rat model (SPZ) and sciatic nerve injury (SNI)-induced hyperalgesia in rats. Propoxazepam (3 mg/ $\mathrm{kg})$ ) proved statistically significant analgesic effect compare to the control and ketorolac values after acute application in TFT and SNI-induced hyperalgesia in rats. Propoxazepam ( $2 \mathrm{mg} / \mathrm{kg}$ ) compare to gabapentin $(5 \mathrm{mg} / \mathrm{kg})$ in greater degree after both single and chronic administrations showed analgesic action in SPZdiabetic rats. Propoxazepam administration reduced bradykinin-induced (0.01\%) hyperalgesia. At a low dose $(1 \mathrm{mg} / \mathrm{kg})$ flumazenil diminished Propoxazepam antinociceptive effect while at a higher dose $(10 \mathrm{mg} / \mathrm{kg})$ had nearly no influence, possibly due to GABAAreceptor complex stabilization. This suggests 
that Propoxazepam causes both nociceptive and neuropathic analgesia in rats and $\mathrm{GABA}_{\mathrm{A}^{-}}$ receptor and bradykinin B-receptor are key sites of analgesic action of propoxazepam.

\section{Conclusions}

The study established the anti-inflammation effects caused by oral administration of a novel synthetic 1,4-benzodiazepine analogue, 7-bromo-5-(2-chlorophenyl)-3-propoxy-1 H-benzo[e] $[1,4]$ diazepin-2(3H)-one (Propoxazepam) into the rats and mouse models with induced inflammation and nociception and explored potential mechanisms of its action. It was proved for the first time that the administration of Propoxazepam had significant anti-inflammatory action when tested in different in vivo chemicals experimental models of induced inflammation, namely carrageenan-, bradykininand formalin-induced inflammationtion tests.
The mechanism of Propoxazepam action might be the inhibition of synthesis or release of inflammatory mediators. As a result of the notable biological activity of Propoxazepam it would be applicable to conduct additional research to implement it into medical practice.

\section{Funding}

This research received no external funding.

\section{Conflict of Interests}

The authors declare no conflict of interest.

Author Contributions

N.Ya. Golovenko - conceptualization, project administration, writing (review and editing), T.A. Kabanova - investigation, resourses, writing (original draft), S.A. Andronati-conceptualization, project administration, writing (review and editing), O.I. Halimova - investigation, resourses. V.B. Larionov - formal analysis, visualization writing, data curation. A.S. Reder - conceptualization, resourses, supervision

\title{
ПРОТИЗАПАЛЬНІ ЕФЕКТИ ПРОПОКСАЗЕПАМУ НА РІЗНИХ МОДЕЛЯХ ЗАПАЛЕННЯ
}

\author{
М.Я. Головенко, Т.А. Кабанова, С.А. Андронаті, \\ О.І. Халімова, В.Б. Ларіонов, А.С. Редер \\ ФІЗИКО-ХІМІЧНИЙ ІНСТИТУТ ІМ. О.В. БОГАТСЬКОГО НАЦІОНАЛЬНОЇ АКАДЕМІЇ НАУК УКРАЇНИ, \\ ОДЕСА, УКРАЇНА
}

Вступ. Пропоксазепам, 7-бром-5(2-хлорфеніл)-3-пропоксі-1Н-бензо[е][1,4]діазепін-2(3Н)-он розглядається, як перспективний анальгетик і антиконвульсант, і станом на сьогодні проходить доклінічні випробування.

Мета. Вивчити протизапальні властивості та аналгетичну активність пропоксазепаму.

Методи. Протизапальна активність була визначена на моделі карагінан-індукованого набряку лапи щурів, викликаної формаліном відповіді лизання у мишей та брадикінінової моделі болю у щурів.

Результати. Вперше було продемонстровано, що застосування пропоксазепаму викликало значний протизапальний ефект у різних тестах in vivo викликаного хімічними речовинами запалення, а саме карагінану, брадикініну та формаліну.

Висновки. Пропоксазепам значно зменшує інтенсивність гострого та підгострого запалення та проявляє протизапальну активність, співставну з референтними препаратами.

КЛЮЧОВІ СЛОВА: пропоксазепам; диклофенак натрію; протизапальна дія; карагінан; формалін.

\section{Інформація про авторів}

Микола Головенко - академік Національної академії медичних наук України, доктор біологічних наук, професор, головний науковий співробітник лабораторії фізико-хімічної фармакології відділу медичної хімії Фізико-хімічного інституту імені О.В. Богатського НАН України.

Тетяна Кабанова - кандидат біологічних наук, старший науковий співробітник відділу медичної хімії Фізико-хімічного інституту імені О.В. Богатського НАН України.

Сергій Андронаті - академік Національної академії наук України, доктор хімічних наук, професор, директор Фізико-хімічного інститут імені О.В. Богатського НАН України.

Олена Халімова - кандидат біологічних наук, науковий співробітник відділу медичної хімії Фізико-хімічного інституту імені О.В. Богатського НАН України.

Віталій Ларіонов - доктор біологічних наук, завідувач лабораторії фізико-хімічної фармакології відділу медичної хімії Фізико-хімічного інституту імені О.В. Богатського НАН України.

Анатолій Редер - кандидат хімічних наук, старший науковий співробітник Фізико-хімічного інституту імені О.В. Богатського НАН України. 


\section{Information about the authors}

Mykola Golovenko - Ph.D., DSc, academician of National academy of Medical Sciences of Ukraine, Chief Researcher of laboratory of Physico-Chemical Pharmacology of Medicinal Chemistry Department, A.V. Bogatsky Physico-Chemical Institute of NAS of Ukraine, Odesa, Ukraine.

ORCID 0000-0003-1485-128X, e-mail: n.golovenko@gmail.com

Tatyana Kabanova - Ph.D., Senior researcher of Medicinal Chemistry Department of A.V. Bogatsky Physico-Chemical Institute of NAS of Ukraine, Odesa, Ukraine.

Sergiy Andronati - Ph.D., DSc in Chemistry, academician of National Academy of Sciences of Ukraine, director of A.V. Bogatsky Physico-Chemical Institute of NAS of Ukraine, Odesa, Ukraine.

ORCID 0000-0001-8451-6327

Olena Halimova - Ph.D., researcher of Medicinal Chemistry Department of A.V. Bogatsky PhysicoChemical Institute of NAS of Ukraine, Odesa, Ukraine.

Vitalii Larionov - Ph.D., DSc, Head of Laboratory of Physical-Chemical Pharmacology of Medicinal Chemistry Department of A.V. Bogatsky Physico-Chemical Institute of NAS of Ukraine, Odesa, Ukraine. ORCID 0000-0003-2678-4264

Anatoliy Reder - Ph.D., Senior Researcher of A.V. Bogatsky Physico-Chemical Institute of NAS of Ukraine, Odesa, Ukraine.

ORCID 0000-0002-1801-8378

\section{References}

1. Khan I, Anupama, Singh B. 1,4-Benzodiazepine: An overview of biological properties. Sci Revs Chem Commun. 2015;5(1):13-20.

https://www.tsijournals.com/articles/14benzodiazepine-overview-of-biological-properties.pdf

2. Zeilhofer HU. The glycinergic control of spinal pain processing. Cell Mol Life Sci. 2005;62:2027-35. doi: 10.1007/s00018-005-5107-3.

3. Twyman RE, Rogers CJ, Macdonald RL. Differential regulation of gamma-aminobutyric acid receptor channels by diazepam and phenobarbital. Ann Neurol. 1989;25(3):213-20.

doi: 10.1002/ana.410250302

4. File SE, Pearce JB. Benzodiazepines reduce gastric ulcers induced in rats by stress. Br J Pharmacol. 1981;74(3):593-9.

doi: $10.1111 /$ j.14765381.1981. tb 10469.x

5. Snow AE, Horita A. Interaction of apomorphine and stressors in the production of hyperthermia in the rabbit. J Pharmacol Exp Ther. 1982;220:335-9.

6. Wilson A. Comparison of flurbiprofen and alprazolam in the management of chronic pain syndrome. Psychiatr J Univ Ott. 1990;15(3):144-9.

7. Golovenko NYa, Voloshchuk NI, Andronati SA, Taran IV, Reder AS, Pashynska OS, et al. Antinociception induced by a novel benzodiazepine receptor agonist and bradykinin receptor antagonist in rodent acute and chronic pain models. EJBPS. 2018;5(12):79-88.

8. Larionov VB, Reder AS. Propoxazepam, a novel analgesic with multifunctional mechanism of action: review of preclinical data. International scientific and practical conference «Prospects for the development of medicine in EU countries and Ukraine», Wloclavek, Republic of Poland, December 2018, 21-22; 111-5.

9. Desai A, Kherallah Y, Szabo C, Marawar R. Gabapentin or pregabalin induced myoclonus: A case series and literature review. J Clin Neurosci. 2019;61:225-34.

doi: 10.1016/j.jocn.2018.09.019

10. Kidd BL, Urban LA. Mechanisms of inflammatory pain. Br J Anaesth. 2001;87:3-11.

doi: $10.1093 / \mathrm{bja} / 87.1 .3$

11. Karateev $A E$, Karateev DE, Davydov OS. Pain and inflammation. Part 2. The analgesic potential of anti-inflammatory drugs. Nauchno-Prakticheskaya Revmatologiya $=$ Rheumatology Science and Practice . 2017;55(1):58-67.

doi: 10.14412/1995-4484-2017-58-67

12. Schlumpf $M$, Parmar $R$, Bütikofer $E E$, Inderbitzin S, Salili AP, Schreiber AA, et al. Delayed developmental neuro- and immunotoxicity of benzodiazepines. Archives of Toxicology. Supplement 1995; 17:261-87.

doi: 10.1007/978-3-642-79451-3_22

13. da Silva FR, Lazzarini $R$, de Sa-Rocha LC, Morgulis MS, Massoco OC, Palermo-Neto J. Effects of acute and long-term diazepam administrations on neutrophil activity: a flow cytometric study. European Journal Pharmacology. 2003;478(2-3):97-104. doi: 10.1016/j.ejphar.2003.08.046

14. Lazzarini $R$, Malucelli BE, Muscará $M N$, de Nucci G, Palermo-Neto J. Reduction of inflammation in rats by diazepam: tolerance development. Life sciences. 2003 Apr 11;72(21):2361-8.

doi: 10.1016/s0024-3205(03)00136-x

15. Lazzarini R, Maiorka PC, Liu J, Papadopoulos V, Palermo-Neto J. Diazepam effects on carrageenaninduced inflammatory paw edema in rats: role of nitric oxide. Life sciences. 2006 May 22;78(26):3027-34. doi: $10.1016 /$ j.Ifs.2005.11.032

16. Pavlovskyi VI, Semenishina KO, Andronati SA, Kabanova TA, Halimova OI, Reder AS. Use of 3-alkoxy1,2-dihydro-3h-1,4-benzodiazepine-2-ons as highly 
active analgesic agents. UA 108246 Ukrainian patent. 2015.

17. Reder A, Larionov V, Golovenko N, Andronati S. Influence of Particle Size on The Anticonvulsant Activity of Propoxazepam. To Chemistry Journal. 2019;2:132-41.

18. Chau TT, Lewin AC, Walter TL, Carlson RP, Weichman BM. Evidence for a role of bradykinin in experimental pain models. Agents and actions. 1991 Sep 1;34(1-2):234-8.

doi: 10.1007/bf01993290

19. Tjølsen A, Berge OG, Hunskaar S, Rosland JH, Hole K. The formalin test: an evaluation of the method. Pain. 1992 Oct 1;51(1):5-17.

doi: 10.1016/0304-3959(92)90003-t

20. Capasso F, Balestrieri B, Di Rosa M, Persico P, Sorrentino L. Enhancement of carrageenin foot oedema by 1, 10-phenanthroline and evidence for the bradykinin as endogenous mediator. Agents and actions. 1975 Oct 1;5(4):359-63.

doi: 10.1007/BF02205243

21. Lazzarini R, Paulino CA, Malucelli BE, PalermoNeto J. Effects of high doses of diazepam on carrageenin-induced paw edema in rats. Brazilian journal of medical and biological research= Revista brasileira de pesquisas medicas e biologicas. 1996 Nov;29(11):1525-9.

22. Lazzarini R, Maiorka PC, Liu J, Papadopoulos V, Palermo-Neto J. Diazepam effects on carrageenaninduced inflammatory paw edema in rats: role of nitric oxide. Life sciences. 2006 May 22;78(26):5345-52. doi: 10.1016/j.Ifs.2005.11.032

23. Wilson A. Comparison of flurbiprofen and alprazolam in the management of chronic pain syndrome. Psychiatric journal of the University of Ottawa: Revue de psychiatrie de I'Universite d'Ottawa. 1990 Sep;15(3):144-9.

24. Zavala FL, Taupin VE, Descamps-Latscha BE. In vivo treatment with benzodiazepines inhibits murine phagocyte oxidative metabolism and production of interleukin 1, tumor necrosis factor and interleukin-6. Journal of Pharmacology and Experimental Therapeutics. 1990 Nov 1;255(2):442-50.

25. Hunskaar S, Hole K. The formalin test in mice: dissociation between inflammatory and non-inflammatory pain. Pain. $1987 \mathrm{Jul}$ 1;30(1):103-14.

doi: 10.1016/0304-3959(87)90088-1

26. McNamara CR, Mandel-Brehm J, Bautista DM, Siemens J, Deranian KL, Zhao M, Hayward NJ, Chong JA, Julius D, Moran MM, Fanger CM. TRPA1 mediates formalin-induced pain. Proceedings of the National Academy of Sciences. 2007 Aug 14;104(33):13525-30. doi: $10.1073 /$ pnas.0705924104

27. Rovati LC, Sacerdote $P$, Fumagalli $P$, Bianchi $M$, Mantegazza $P$, Panerai AE. Benzodiazepines and their antagonists interfere with opioid-dependent stress-induced analgesia. Pharmacology Biochemistry and Behavior. 1990 May 1;36(1):123-6.

doi: 10.1016/0091-3057(90)90136-6

28. Kidd BL, Urban LA. Mechanisms of inflammatory pain. British journal of anaesthesia. $2001 \mathrm{Jul}$ 1;87(1):3-11.

doi: $10.1093 / \mathrm{bja} / 87.1 .3$

29. Belowska-Bień K, Szeląg E, Szeląg J, SkrzypiecSpring M. Bradykinin-an undervalued mediator?. Post N Med. 2017; XXX(08):440-6.

30. Couture R, Harrisson M, Vianna RM, Cloutier F. Kinin receptors in pain and inflammation. European journal of pharmacology. 2001 Oct 19;429(1-3): 161-76.

doi: 10.1016/S0014-2999(01)01318-8

31. Virych PA, Shelyuk OV, Kabanova TA, Khalimova EI, Martynyuk VS, Pavlovsky VI, Andronati SA. Effect of 3-substituted 1, 4-benzodiazepin-2-ones on bradykinin-induced smooth muscle contraction. The Ukrainian Biochemical Journal. 2017;89(1):31-7.

doi: $10.15421 / 021735$

Received 01 September 2019; revised 10 October 2019; accepted 21 October 2019

This is open access article distributed under the Creative Commons Attribution License, which permits unrestricted use, distribution, and reproduction in any medium, provided the original work is properly cited. 